\title{
Assessing the Use of Electronic Recruitment in Travel Agents and Hotels in Egypt
}

\section{Mohammed Ezzat}

Lecturer - Tourism Studies Department

Faculty of Tourism and Hotel, Minia University

\section{Muhammad Abd El Monem Ebraheem Abd El Salam}

\author{
Lecturer - Tourism Studies Department
}

Faculty of Tourism and Hotel, Minia University

\begin{abstract}
This research was conducted to give an overall assessment of the effectiveness of using electronic recruitment in travel agents and hotels in Egypt. The success of the tourism and hospitality industry depends on the quality of its employees and their effective management. E-recruitment is becoming a significant part of the recruitment strategy of all companies world-wide, in addition to becoming an increasingly popular method for job seekers in searching and applying for jobs. This research was applied on a sample of travel agents - category "A" and hotels in Egypt. A survey questionnaire was distributed from June to August 2017. About 300 forms were distributed, and the number of valid forms was 271 (133 from travel agents and 138 from hotels).

The findings indicated that using e-recruitment in travel agents and hotels was more effectively than traditional methods in hiring. The results showed that there was a statistically significance correlation between all dimensions of e-recruitment process in travel agents and hotels. Moreover there was a significant difference between travel agencies and hotels and this difference was in favor of travel agencies in the dimensions of methods of recruitment and benefits of e-recruitment. On the other hand there is no significant difference between travel agents and hotels in the dimensions of disadvantage of e-recruitment process for hotels.

This study presented few recommendations for hotels and travel agents such as: developing policies and procedures that will promote e-recruitment because of its contribution to reduce the cost of e-recruitment in the company; using variety of more methods of e-recruitment to attract new employee, and developing special software that will facilitate the search for the most efficient candidates who submitted their applications through the company's website.
\end{abstract}

Key Words: E-Recruitment- Online Recruitment- Travel Agents - Hotels- Egypt Introduction 
The first step amongst the obvious functions of human resource management is recruitment. Recruitment is a process to discover the sources of work force to meet the requirements of the staffing schedule and to employ effective measures for attracting adequate number of work force to facilitate effective selection of an efficient team of officials. Recruitment acts as a precondition to selection function, and effective recruitment will lead to a very successful hiring for any organization (Huda et al, 2014).

Tourism and hospitality industry is renowned for having high labor turnover rates and an element of hard to fill vacancies and attracting suitable employees remains an on-going challenge.(Ladkin and Buhalis, 2016). The term online recruitment, e-recruitment, or internet recruiting implies the formal sourcing of jobs online (Galanaki, 2002). The first references to e-recruitment appear in articles of the mid-1980s (Sharma, 2011.; Kumudha and SaranyaPriyadarshini, 2014). Erecruitment has been an issue of interest over the past years. Internet is considered as the latest tool in hiring. It is a real revolution spreading over the world of job hunting and hiring. (Sharma, 2011).

Gamage (2014) defines recruitment process as a systematic process of recruiting candidates for any firm consisting of job analysis, job description, advertising mode and conducting interviews followed by screening, selection and evaluation. As the recruitment process takes most of the time and is expensive, firms often prefer to e-recruitment. There is a positive and important correlation among recruitment and selection and the enterprise's performance (Gamage, 2014; Nadda et al, 2017). Kaur (2015) mentioned that e-recruitment stages is $70 \%$ faster than other traditional hiring methods, and costs of posting jobs and searching for candidates on job portals can be up to $90 \%$ lower than the costs of using traditional methods.

There will always be a need for hiring new employees, and finding effective ways to recruit people is a key issue for the business world of today. All the time companies are trying to find more conventional ways to recruit more people and companies have discovered that web-based hiring is more efficient than the traditional ways (Aspridis et al, 2013, p.29).

There are little research papers that studied the effectiveness of electronic recruitment generally and in the tourism field specifically. From this sprang, the contribution of current study is to fill the above-mentioned gap in tourism literature. The main purpose of this study is to give an overall assessment of effectiveness of using electronic recruitment and selection process in Travel Agents and Hotels in Egypt. More specifically, the objectives of this current study are as follows:

- Identifying the methods of e-recruitment used by travel agents and hotels in Egypt.

- Shedding light on the benefits of e-recruitment process for travel agents and hotels.

- Shedding light on the disadvantages of e-recruitment process for travel agents and hotels.

- Identifying the success evaluating factors of e-recruitment process in travel agents and hotels. (To outline the criteria for effective e-recruitment) 


\section{Literature Review}

Tourism and hospitality industry is a dynamic service sector where optimal human resource management is required to ensure professionalism and efficiency in service delivery. As a result, it is challenging for the travel agents and hotels to recruit and develop potential service providers to provide better services for tourists (Huda et al, 2014). The success of the tourism and hospitality industry depends on the quality of its employees and their effective management in order to assist the organization to achieve its objectives (Sharma, 2011; Berger and Ghei, 1995).

E-recruitment is a part of electronic Human Resource Management (e-HRM). E-recruitment is defined as the use of the internet to attract potential employees to an organization and hire them (Ghazzawi and Accoumeh, 2014). Moreover, e-recruitment is defined as the practice of using technology and in particular Web-based resources for tasks involved with finding, attracting, assessing, interviewing and hiring new personnel (Kumudha and Saranya Priyadarshini, 2014). According to the Pew Internet Research reported by NAS insights (2006), Internet proved to be an integral part of employee recruitment because there was no faster, simpler, or more cost effective way to reach thousands of qualified candidates. In fact, $44 \%$ of online Americans were looking for information about a job. The Internet allowed HR Managers to reach these candidates 24 hours a day, 7 days a week (Nas, 2006). There are a lot of e-recruiting activities and processes specifically online job posting such as on corporate websites or job portals, receiving of applications over the Internet, storage of these applications, screening applications, online tests, response and status management (Singh and Narang, 2008.; Mat Zin et al, 2016). There are three main steps in the erecruitment process. These are known within the industry as the three Es". These are: attracting applications, managing applications and selecting candidates. It is important for any potential employer to have a plan involving these three Es in order to successfully hire the right candidate (Shahila and Vijayalakshmi , 2013)

E-Recruitment technology is employed by organizations due to numerous reasons including attracting candidates, informing benefits about the organization and assessing applicants' knowledge, skills, abilities and other requirements (such as personalities (Mat Zin et al, 2016). Nevertheless, Borck (2000) added that e-recruitment need to be used in combination with other techniques and it should not replace traditional recruiting but must be implemented together. Also Cullen (2001) supported that e-recruitment should not be a stand-alone tool as it can be assimilated into a general recruiting and selection strategy. Some potential challenges of erecruitment includes discrimination between internet users and non-user, enormous volume of unqualified and low quality candidates (Galanaki, 2002), user unfriendly tools (Feldman and Klaas, 2002) and lack of personal touch (Mat Zin et al., 2016).

\section{The Methods of E-Recruitment}

Using the internet to attract and recruit potentials employees can be done in a number of ways: (The Public Appointments Service, 2006; Kaur, 2015)

- Company websites (Corporate websites):

Company websites is an important tool for e-recruitment which often plays a significant role in recruiting job applicants through advertising posts and providing information to 
candidates (Allen et al., 2007). Ladkin and Buhalis (2016) stated that $75 \%$ of organizations use their own websites to attract applicants, primarily large brands such as Marriott. Many of the large hotel chains (for example, Hyatt, Marriott and Four Seasons) have links to career opportunities on their sites, incorporating further opportunities to connect through Face book, LinkedIn and Twitter, RSS and Blogs.

- Job Boards (commercial jobs boards) :

These are the places where the employers post jobs and search for candidates. Commercial general purpose recruitment portals, (such as, naukri.com, timesjob.com, monster.com, etc) or niche job boards aimed at a specific industry. One of the disadvantages is that it is generic in nature. Special skill candidates can be searched by certain job boards (Kaur, 2015).

\section{- Professional websites:}

These are for specific professions, skills and not general in nature. For an example, for HR jobs Human Resource Management sites to be visited like www.shrm.org. The professional associations will have their own site or society (Kaur, 2015).

- Online Searching - Recruiters searching online sources such as company websites/professional chat sites/organizational profiles etc. to identify potential candidates who may not be actively looking for a job.

- Relationship recruiting - Using the internet to build and maintain long term relationships with passive candidates, through using internet tools to learn more about web visitors' interests and experience and to e-mail regular updates about careers and their fields of interest.

\section{- E-Recruitment via Social Media Sites:}

The practice of using social networking sites for recruitment screening and selection has become more and more popular (Kroeze, 2015). Melanthious et al. (2015) consider recruitment through social media to be a positive thing.

A Survey carried out by Society for Human Resource Management (SHRM) revealed that $77 \%$ of companies under investigation used social networking sites to recruit applicants which were up from 34\% in 2008 and 56\% in 2011. Another research by Career Builder revealed $43 \%$ of employers use social networking to research job applicants which was up from $36 \%$ in 2012 and 39\% in 2013 (Sameen and Cornelius, 2013)

\section{Benefits of E-Recruitment}

Electronic recruitment has longer lifetime cycle and in many cases it is also free, or at least cheaper than advertising in newspapers. Nowadays, people that are seeking work are based on the Internet, for example in social media websites where thousands of new job ads are posted and advertised daily (Aspridis et al, 2013, p.29). There are many benefits or advantages of erecruitment such as: 
- E- Recruitment has become an easy way to save costs (Hart and Chadwick, 2000; Cappelli, 2001). Costs of posting jobs and searching for candidates on job portals can be up to $90 \%$ lower than the costs of using traditional search firms and/or advertising methods. (Kaur, 2015).

- E- Recruitment Reduced time-to-hire (Hart and Chadwick, 2000; Cappelli, 2001, Saini and Chauhan, 2016). On average, the e-recruitment stages is $70 \%$ faster than traditional hiring methods with recruiting process is speeded up at every stage from posting, to receiving CVs, to filtering it, managing the contacts and workflow (Kaur, 2015).

- There is growing evidence that organizations are using e-recruitment because it improves corporate image and profile, reduces recruitment costs and reduces administrative burden . (Shahila and Vijayalakshmi,2013)

- Online recruitment is effective in terms of speedy information collection of applicant, giving detailed and uniform data to the applicant sand time saving (Gopalia,2012, p.13)

- E-recruitment and selection in terms of reduced recruitment cost, hiring of quality candidates and quick selection process. (Kerrin, 2005.;Gopalia,2012, p.14)

- Online recruitment is also effective in terms of performing talent management process (Burbach and Royle, 2010., Saini and Chauhan, 2016

- The Internet allowed HR Managers to reach these candidates 24 hours a day, 7 days a week. (Nas, 2006)

- Online recruiting is significantly more cost-effective and efficient than other media such as newspapers (Nas,2006)

- More opportunities for smaller companies. (Pin et al, 2001).

- E-recruitment gives the company Positive effect on corporate image/up-to-date image (Galanaki, 2002; Mat Zin et al, 2016)

- Internet can assist employees in finding employment opportunities faster and easier than ever before (Kumar, 2003).

- An advantage OF E- recruitment for employers is that the effective range in which recruiters can search for applicants is much broader. Recruiters can easily access both national and international applicants (Kroeze, 2015).

- E-recruitment has many advantages like; a shorter recruitment cycles, bigger pool of experienced candidates, efficient selection of best candidates and Improved quality of candidates (Anna, 2010).

\section{Disadvantages of E-Recruitment Process}

There are a number of disadvantages in e-recruitment process as follows: firstly the abundance of applicants; because the Internet is accessible to people all over the world, the employer is likely to get swamped with resumes from interested candidates. And unfortunately, many of the applicants responding to the ads are not qualified (Ramaabaanu and Saranya, 2014). Secondly, higher expectations regarding relocation costs (Brooke 1998). Thirdly, discrimination/privacy (Bartram 2000; Feldman and Klaas 2002; Pin et al. 2001; Pitturo 2000) and finally, overwhelming number of candidates (Galanaki2002, Haley 2000; Lawrence 1999 cited by Bartram 2000). 


\section{Methodology}

\section{Population and Sample}

The target population of this research was managers and Human resources managers working in hotels and travel agents in Egypt. Both online and offline questionnaires were employed at this study to reach out the target sample during the period from June to august 2017. A total of 300 questionnaires were distributed by the researches to manage who agreed to participate in the study and only 271 usable ones were retrieved. The sample was distributed as 49\% (133 forms) from travel agents and 51\% (138 forms) from hotels as in table 1.

Table 1. Profile of Sampled respondents

\begin{tabular}{|l|c|c|}
\hline & F & $\%$ \\
\hline Travel agents & 133 & 49.1 \\
\hline Hotels & 138 & 50.9 \\
\hline Total & 271 & 100 \\
\hline
\end{tabular}

\section{Survey instrument}

The survey consisted of four main study dimensions as follows: methods of e-recruitment being used by travel agent and hotels in Egypt, benefits of e-recruitment for travel agent and hotels, disadvantage of e-recruitment and Success factors of e-recruitment. This study questionnaire consisted of 28 statements that measure the four main dimensions of this study. The five-point Likert scale was used to measure the sample opinions for each statement.

\section{Data analysis}

All data were analyzed with SPSS version 24 software. First of all, Cronbach's alpha coefficients for each of the survey used in this research were computed using reliability analysis to assess the internal consistency of the measuring instrument. Descriptive statistics such as mean scores and standard deviations were computed according to the dimensions. Pearson correlation analysis applied in order to check the nature of relationship between the dimensions and finally T- test was conducted to identify the differences between hotels and travel agent in Egypt.

The researcher used surveys because according to Robson (2002) surveys are used for relatively large numbers of respondents within a limited time frame. This appears to be the most convenient way to obtain highest participation as people would be able to fill in the questionnaire during free time (Zawawi and kamaruzzaman, 2009).

\section{Results:}

\section{Measurement questionnaire validity and reliability}

\section{- Measure Validity}

In order to verify validity the researcher relied one form of validity: 


\section{○ Content validity (Believe arbitrators)}

The survey questionnaire was judged by a two of arbitrators. These experts reviewed the measurement and its dimensions. Revisions to the questionnaire were made based on feedback from the jury. The researchers responded to the views of the jury and performed the necessary delete and modify in questions with $90 \%$ approval and higher were only considered. 28 statements representing four dimensions has finally identified in questionnaire.

\section{○ Measuring Reliability}

The Cronbach alpha was used to realize the internal steadiness and the reliability of the dimensions that were used in the survey, also to ensure the measurements accuracy. The coefficients of Cronbach's Alpha for all scale's dimensions were greater than (0.70), so the study measurement were acceptable and reliable (Bozorgy, 2007). Details for all dimensions' values of Cronbach's alpha are provided in table 2.

Table 2. The internal reliability of the study dimensions

\begin{tabular}{l|c|c}
\hline \multicolumn{1}{c}{ Dimension } & $\begin{array}{c}\text { No. of } \\
\text { Items }\end{array}$ & $\begin{array}{c}\text { Cronbach's } \\
\text { alpha }\end{array}$ \\
\hline $\begin{array}{l}\text { Methods of recruitment being used by travel agents and } \\
\text { hotels in Egypt }\end{array}$ & 5 & 0.724 \\
\hline Benefits of e-recruitment for travel agents and hotels & 10 & 0.950 \\
\hline $\begin{array}{l}\text { How are travel agents and hotels evaluating the success of e- } \\
\text { recruitment process }\end{array}$ & 9 & 0.927 \\
\hline Disadvantage of e-recruitment process & 4 & 0.822 \\
\hline \multicolumn{1}{c|}{ Overall Scale } & $\mathbf{2 8}$ & 0.950 \\
\hline
\end{tabular}

In assessing the strength of relationship between pairs of e-recruitment dimensions as reported by the sampled travel agencies and hotels, a Pearson's product moment correlation coefficient (PMCC) was used. Table (3) highlighted the following relationships:

- a positive correlation at 0.01 level between all e-recruitment variables (methods of recruitment, benefits of e-recruitment, success factors of e-recruitment, and challenges for erecruitments adoption) with each other ( $\mathrm{r}$ from 0.13 to 0.78 );

- a strong relationship at 0.01 level between benefits of e-recruitment and success factors of erecruitment $(r=0.78)$, methods of recruitment and success factors of e-recruitment $(r=0.72)$, and between methods of recruitment and benefits of e-recruitment $(r=0.70)$;

- a moderate correlation at 0.01 level between benefits of e-recruitment and challenges for erecruitments adoption $(\mathrm{r}=0.36)$; and

- a weak relationship at 0.01 level between methods of recruitment and challenges for erecruitments adoption $(r=0.18)$, and between success factors of e-recruitment and challenges for e-recruitments adoption $(r=0.13)$. 
Table 3. Correlations between the study's variables

\begin{tabular}{|c|c|c|c|c|}
\hline \multicolumn{2}{|l|}{ Variables } & Methods of & Benefits of & $\begin{array}{l}\text { Success factors of e- } \\
\text { recruitment }\end{array}$ \\
\hline \multirow{3}{*}{$\begin{array}{l}\text { Benefits of } \\
\text { e-recruitment }\end{array}$} & $r$ & $0.701 * *$ & & \\
\hline & $\begin{array}{l}\text { Sig. (2- } \\
\text { tailed) }\end{array}$ & 0.000 & & \\
\hline & $\mathrm{N}$ & 271 & & \\
\hline \multirow{3}{*}{$\begin{array}{l}\text { Success factors of e- } \\
\text { recruitment }\end{array}$} & $r$ & $0.717 * *$ & $0.781 * *$ & \\
\hline & $\begin{array}{l}\text { Sig. (2- } \\
\text { tailed) }\end{array}$ & 0.000 & 0.000 & \\
\hline & $\mathrm{N}$ & 271 & 271 & \\
\hline \multirow{3}{*}{$\begin{array}{l}\text { Challenges for } \\
\text { e-recruitments } \\
\text { adoption }\end{array}$} & $r$ & $0.180 * *$ & $0.357 * *$ & $0.131 * *$ \\
\hline & $\begin{array}{l}\text { Sig. (2- } \\
\text { tailed) }\end{array}$ & 0.003 & 0.000 & 0.031 \\
\hline & $\mathrm{N}$ & 271 & 271 & 271 \\
\hline
\end{tabular}

The above stated results illustrate that, the dimensions of e-recruitments move in the same direction and an increase in one variable was correlated with increase another. Accordingly, the knowledge and the awareness of the importance and effects of these variables collectively will lead to a successful adoption of e-recruitments practices in the tourism businesses environment.

In the following section of the study, Descriptive statistics such as mean scores and standard deviations were showed separately for travel agents and hotels who answered the study questionnaire. They had been treated as two independent samples.

\section{Descriptive Statistics of Travel Agents Sample:}

As for the methods of recruitment being used by travel agents in Egypt, the results showed that the highest mean score were social media sites at 3.97, followed by the mean of professional websites at 3.90, and the commercial jobs boards at 3.50, and traditional methods at the last. (Table 4).This finding indicated that the practice of using social networking sites for recruitment screening and selection has become more and more popular this finding agree with (Kroeze, 2015; Melanthious et al., 2015)

Table 4: Descriptive statistics of Methods of recruitment being used by travel agents in Egypt

\begin{tabular}{|c|c|c|c|}
\hline Statements & Mean & SD & Rank \\
\hline E-Recruitment via Social Media Sites & 3.97 & 1.273 & 1 \\
\hline Professional websites & 3.90 & 1.364 & 2 \\
\hline Job Boards (commercial jobs boards) & 3.50 & 1.324 & 3 \\
\hline Company websites & 3.40 & 1.287 & 4 \\
\hline Traditional methods & 2.77 & .976 & 5 \\
\hline Total & 3.50 & .782 & \\
\hline
\end{tabular}


Table 5 showed the benefits of e-recruitment for travel agents. It can be seen that the most benefits were arranged as: saving recruitment cost $(M=4.49)$, followed by e-recruitment available 24 hours/7 days $(M=4.43)$, then Recruiters can easily access both national and international applicants $(M=4.25)$, and more opportunities for smaller companies $(M=4.12)$. The lowest mean score of benefits were: hiring of quality candidates and quick selection process $(M=3.54)$, followed by online recruitment is also effective in terms of managing talent process $(M=3.61)$.

Table 5: Descriptive statistics of benefits of e-recruitment for travel agents

\begin{tabular}{|l|l|l|l|}
\hline \multicolumn{1}{|c|}{ Statements } & Mean & SD & Rank \\
\hline Saving recruitment cost & 4.49 & 1.077 & 1 \\
\hline Reduced time-to-hire & 4.09 & 1.196 & 6 \\
\hline Improves corporate image and profile & 4.02 & 1.206 & 7 \\
\hline $\begin{array}{l}\text { Online recruitment is effective in terms of speedy information } \\
\text { collection of applicant }\end{array}$ & 4.09 & 1.234 & 5 \\
\hline Hiring of quality candidates and quick selection process & 3.54 & 1.340 & 10 \\
\hline $\begin{array}{l}\text { 24 hours a day/ d days a week } \\
\text { More opportunities for smaller companies }\end{array}$ & 4.43 & 1.130 & 2 \\
\hline $\begin{array}{l}\text { Recruiters can easily access both national and international } \\
\text { applicants }\end{array}$ & 4.12 & 1.243 & 4 \\
\hline Wider reach for employers Total & 1.083 & 3 \\
\hline $\begin{array}{l}\text { Online recruitment is also effective in terms of managing talent } \\
\text { process }\end{array}$ & 3.61 & 1.058 & 9 \\
\hline \multicolumn{1}{|c|}{ The } & 4.05 & .991 & 8 \\
\hline
\end{tabular}

Concerning the success factor of e-recruitment process in travel agent, it could be seen that, firstly the high mean of Increased the performance of required tasks was 3.94. Secondly the mean of interesting of personal standards and qualifications was 3.92. Thirdly the mean of increased number of responses for every job openings was 3.77. On the other hand the lowest mean of put the suitable employees in suitable position was 3.29, followed by the Increased new employee satisfaction rate with recruiting process $(\mathrm{M}=3.32)$ (Table 6).

Table 6: Descriptive statistics of success factor of e-recruitment process in travel agent

\begin{tabular}{|c|c|c|c|}
\hline Statements & Mean & SD & Rank \\
\hline Increased number of responses for every job openings & 3.77 & 1.022 & 3 \\
\hline $\begin{array}{l}\text { E- recruitment make interest of personal standard and qualifications } \\
\text { which make justice in recruitment process }\end{array}$ & 3.92 & 1.098 & 2 \\
\hline E- recruitment put suitable employees in suitable position & 3.29 & 1.230 & 8 \\
\hline Increased Number of Submitted applications/ CVs. & 3.56 & 1.252 & 5 \\
\hline Increased new employee satisfaction rate with recruiting process & 3.32 & 1.323 & 7 \\
\hline Increased percentage of new employee retention within a given time & 3.47 & 1.247 & 6 \\
\hline Cost to recruit per job openings & 3.38 & 1.266 & \\
\hline Increased percentage of vacancies filled within a stipulated time. & 3.69 & 1.136 & 4 \\
\hline Increased the performance of required tasks & 3.94 & 1.140 & 1 \\
\hline Total & 3.59 & .945 & \\
\hline
\end{tabular}


The next table showed disadvantages of e-recruitment in travel agents sample.

It can be seen that the most disadvantages were arrange as: the difficulty assurance of source of data and documents as mean 3.67, followed by the large number of forms and CVs of applicants as mean 3.46 and difficult to reach best applicants was 3.5. Finally the mean of difficult of achieving employees' diversity was 2.96 .

Table 7: Descriptive statistics of the disadvantages of e-recruitment in travel agent

\begin{tabular}{|l|l|l|l|}
\hline \multicolumn{1}{|c|}{ Statements } & Mean & SD & Rank \\
\hline the large number of forms and CVs of applicants. & 3.46 & 1.362 & 2 \\
the difficulty in verifying the sources of documents and data. & 3.67 & 1.369 & 1 \\
\hline the difficulty of achieving diversity in employment. & 2.96 & 1.422 & 4 \\
\hline the difficulty of reaching the best candidates. & 3.05 & 1.308 & 3 \\
$\quad$ Total & 3.28 & 1.163 & \\
\hline
\end{tabular}

\section{Descriptive statistics of Hotel's sample:}

From the next table, it can be seen that the highest means of methods of recruitment being used by hotels in Egypt were arranged as: social media sites at 3.59, followed by hotels websites at 3.38, commercial jobs boards at 2.96, professional websites at 2.86, finally traditional methods at 2.23.

Table 8: Descriptive statistics of Methods of recruitment being used by hotels in Egypt

\begin{tabular}{|l|c|c|c|}
\hline \multicolumn{1}{|c|}{ Statements } & Mean & SD & Rank \\
Company websites & 3.38 & .998 & 2 \\
\hline Job Boards (commercial jobs boards & 2.96 & 1.632 & 3 \\
E-Recruitment via Social Media Sites & 3.59 & 1.044 & 1 \\
\hline Professional websites & 2.86 & 1.534 & 4 \\
\hline Traditional methods $\quad 2.23$ & 1.048 & 5 \\
\hline \multicolumn{1}{|c|}{ Total } & 3.01 & .936 & \\
\hline
\end{tabular}

As for the benefits of e-recruitment for hotels, it could be seen from the table 9 that the most benefits were arranged as: e-recruitment available 24 hours for 7 days at 4.1 , followed by saving recruitment cost at 399, and recruiters can easily access both national and international applicant at 3.91. On the other hand, the lowest mean of improves corporate image and profile was 3.21, followed by e-recruitment is also effective in terms of managing talent process at 3.28. This finding indicated that e-recruitment was available 24 hours all 7 days that enable the hotel management to obtain the large number of applicants in short time. This finding agree with Alfus 2001; Bartram 2000; Burke 1998; Pin et al. 2001; Zusman and Landis 2002).

Table 9: Descriptive statistics of benefits of e-recruitment for hotels

\begin{tabular}{|l|c|c|c|}
\hline \multicolumn{1}{|c|}{ Statements } & Mean & SD & Rank \\
\hline saving recruitment cost & 3.99 & 1.336 & 2 \\
\hline Reduced time-to-hire & 3.37 & 1.246 & 7 \\
\hline improves corporate image and profile & 3.21 & .902 & 10 \\
\hline Online recruitment is effective in terms of speedy information & 3.67 & 1.019 & 6 \\
\hline
\end{tabular}




\begin{tabular}{|l|c|c|c|}
\hline $\begin{array}{l}\text { collection of applicant } \\
\text { hiring of quality candidates and quick selection process }\end{array}$ & 3.32 & 1.159 & 8 \\
\hline 24 hours a day‘/7 days a week & 4.01 & 1.199 & 1 \\
\hline More opportunities for smaller companies & 3.67 & 1.019 & 5 \\
\hline $\begin{array}{l}\text { Recruiters can easily access both national and international } \\
\text { applicants }\end{array}$ & 3.91 & 1.087 & 3 \\
\hline Wider reach for employers & 3.68 & 1.213 & 4 \\
\hline $\begin{array}{l}\text { Online recruitment is also effective in terms of managing talent } \\
\text { process }\end{array}$ & 3.28 & 1.094 & 9 \\
\hline \multicolumn{1}{|c|}{ Total } & 3.57 & .898 & \\
\hline
\end{tabular}

Concerning the success factor of e-recruitment process in hotels, it could be stated that, firstly the high mean of increased percentage of new employee retention within a given timed was 3.75. Secondly the mean of increased number of submitted applications/ CVs. was 3.68. Thirdly the mean increased new employee satisfaction rate with recruiting process was 3.67. On the other hand the lowest mean of increased number of responses for every job openings was 3.4 and interesting personal standard and qualifications was 3.4

Table 10: Descriptive statistics of success factors of e-recruitment process in hotels

\begin{tabular}{|l|l|l|l|}
\hline \multicolumn{1}{|c|}{ Statements } & Mean & SD & Rank \\
\hline Increased number of responses for every job openings & 3.04 & 1.117 & 8 \\
\hline $\begin{array}{l}\text { E recruitment make interest of personal standard and qualifications } \\
\text { which make justice in recruitment process }\end{array}$ & 3.04 & 1.080 & 9 \\
\hline E-recruitment put suitable employees in suitable position & 3.09 & .875 & 7 \\
\hline Increased Number of Submitted applications/ CVs. & 3.68 & 1.046 & 2 \\
\hline $\begin{array}{l}\text { Increased new employee satisfaction rate with recruiting process } \\
\text { Increased percentage of new employee retention within a given } \\
\text { time }\end{array}$ & 3.67 & .915 & 3 \\
Cost to recruit per job openings. & 3.41 & .811 & 1 \\
\hline Increased percentage of vacancies filled within a stipulated time. & 3.45 & 1.166 & 4 \\
\hline Increased the performance of required tasks & 3.39 & .759 & 6 \\
\hline \multicolumn{1}{|c|}{ Total } & 3.39 & .812 & \\
\hline
\end{tabular}

The next table showed disadvantage of e-recruitment in hotels. The results indicated that the high mean of the large number of forms and CVs of applicants was 3.83. The mean of difficult assurance of source of data and documents was 3.49. The mean of difficult to reach best applicants was 3.25. Finally the mean of difficult of achieving employees' diversity was 2.17. (table 11).

Table 11: Descriptive statistics of disadvantage of e-recruitment in hotels

\begin{tabular}{|l|l|l|l|}
\hline Statements & Mean & SD & Rank \\
\hline the large number of forms and CVs of applicants. & 3.83 & 1.036 & 1 \\
\hline the difficulty in verifying the sources of documents and data. & 3.49 & 1.319 & 2 \\
\hline the difficulty of achieving diversity in employment. & 3.25 & 1.018 & 3 \\
the difficulty of reaching the best candidates. & 3.17 & .782 & 4 \\
\hline \multicolumn{1}{|c|}{ Total } & 3.44 & .744 & \\
\hline
\end{tabular}


An independent-samples t-test was conducted to compare opinions between travel agencies and hotels towards e-recruitments variables. Table 12 compared response on e-recruitments variables by sampled travel agencies and hotels. For methods of recruitment, the mean for travel agencies group valued at 3.50 and for hotels it was 3.01, a difference of 0.499 . In this case t had a value of 4.751 and a significance level of 0.000 . T-test results showed that there is a significant statistical difference between their views on the effects of those methods. This referred difference was in favour of travel agencies [ $t(269)=4.751 \mathrm{p}<.05]$ (Table 3).

Similarly, a statistically significant difference found between travel agencies and hotels' responses in terms of benefits of e-recruitment in favor of travel agencies [ $t(269)=4.204 p<.05]$ (Table 13). In this case, the mean for travel agencies was 4.05 and for hotels valued at 3.57, a difference of 0.483 , and $t$ had a value of 4.204 at a significance level of 0 (Table 12).

As for, the other two study's variables, the success factors of e-recruitment and disadvantages for e-recruitments adoption, the significant levels were 0.056 and 0.185 respectively (Table 13). Since these values are above 0.05 , so the null hypothesis is accepted that there was no significant difference between the travel agencies and hotels.

These abovementioned findings revealed that methods of recruitment followed by travel agencies are different from those of hotels and in results the benefits gained for the adoption of erecruitment methods were not the same. However, the success factors adoption's disadvantages of e-recruitments were reported in equal point of views by travel agencies and hotels.

Table 12: Descriptive statistics of sample responses on e-recruitments variables by type of tourism business

\begin{tabular}{|c|c|c|c|c|c|}
\cline { 2 - 5 } \multicolumn{1}{c|}{} & $\begin{array}{c}\text { Type of } \\
\text { Tourism } \\
\text { Business }\end{array}$ & $\mathrm{N}$ & Mean & $\begin{array}{c}\text { Std. } \\
\text { Deviation }\end{array}$ & Std. Error Mean \\
\hline \multirow{2}{*}{ Methods of recruitment } & $\begin{array}{c}\text { Travel } \\
\text { Agencies }\end{array}$ & 133 & 3.50 & 0.782 & 0.068 \\
\cline { 2 - 6 } & Hotels & 138 & 3.01 & 0.936 & 0.080 \\
\hline \multirow{2}{*}{$\begin{array}{c}\text { Benefits of } \\
\text { e-recruitment }\end{array}$} & $\begin{array}{c}\text { Travel } \\
\text { Agencies }\end{array}$ & 133 & 4.05 & 0.991 & 0.086 \\
\cline { 2 - 6 } & Hotels & 138 & 3.57 & 0.898 & 0.076 \\
\hline \multirow{2}{*}{$\begin{array}{c}\text { Success factors of e-recruitment } \\
\text { Agencies }\end{array}$} & 133 & 3.59 & 0.945 & 0.082 \\
\cline { 2 - 6 } & Hotels & 138 & 3.39 & 0.812 & 0.069 \\
\hline \multirow{2}{*}{$\begin{array}{c}\text { e-recruitments adoption } \\
\text { disadvantages of }\end{array}$} & $\begin{array}{c}\text { Agencies } \\
\text { Hotels }\end{array}$ & 133 & 3.28 & 1.163 & 0.101 \\
\cline { 2 - 6 } & Hovel & 3.44 & 0.744 & .063 \\
\hline
\end{tabular}


Table 13:t test results of sample scores with respect to type of tourism business

\begin{tabular}{|c|c|c|c|c|c|c|c|c|c|c|}
\hline & \multicolumn{2}{|c|}{$\begin{array}{l}\text { Levene's } \\
\text { Test for } \\
\text { Equality of } \\
\text { Variances }\end{array}$} & \multicolumn{7}{|c|}{ t-test for Equality of Means } \\
\hline & & \multirow[t]{2}{*}{$\mathrm{F}$} & \multirow[t]{2}{*}{ Sig. } & \multirow[t]{2}{*}{$\mathrm{t}$} & \multirow[t]{2}{*}{ df } & \multirow[t]{2}{*}{$\begin{array}{l}\text { Sig. } \\
(2- \\
\text { tailed })\end{array}$} & \multirow[t]{2}{*}{$\begin{array}{c}\text { Mean } \\
\text { Difference }\end{array}$} & \multirow[t]{2}{*}{$\begin{array}{l}\text { Std. Error } \\
\text { Difference }\end{array}$} & \multicolumn{2}{|c|}{$\begin{array}{c}95 \% \\
\text { Confidence } \\
\text { Interval of } \\
\text { the } \\
\text { Difference }\end{array}$} \\
\hline & & & & & & & & & Lower & Upper \\
\hline \multirow{2}{*}{$\begin{array}{l}\text { Methods of } \\
\text { recruitment }\end{array}$} & $\begin{array}{c}\text { Equal } \\
\text { variances } \\
\text { assumed } \\
\end{array}$ & 12.187 & .001 & $\underline{4.751}$ & 269 & $\underline{0.000}$ & 0.499 & .105 & .292 & .705 \\
\hline & $\begin{array}{c}\text { Equal } \\
\text { variances } \\
\text { not } \\
\text { assumed }\end{array}$ & & & 4.767 & 263.752 & 0.000 & 0.499 & .105 & .293 & .705 \\
\hline \multirow{2}{*}{$\begin{array}{l}\text { Benefits of } \\
\text { e- } \\
\text { recruitment }\end{array}$} & $\begin{array}{c}\text { Equal } \\
\text { variances } \\
\text { assumed }\end{array}$ & 1.061 & .304 & $\underline{4.204}$ & 269 & $\underline{0.000}$ & 0.483 & .115 & .257 & .709 \\
\hline & $\begin{array}{c}\text { Equal } \\
\text { variances } \\
\text { not } \\
\text { assumed }\end{array}$ & & & 4.196 & 264.194 & 0.000 & 0.483 & .115 & .256 & .709 \\
\hline \multirow{2}{*}{$\begin{array}{c}\text { Success } \\
\text { factors of e- } \\
\text { recruitment }\end{array}$} & $\begin{array}{c}\text { Equal } \\
\text { variances } \\
\text { assumed } \\
\end{array}$ & 5.943 & .015 & 1.917 & 269 & $\underline{0.056}$ & 0.205 & .107 & $-.006-$ & .415 \\
\hline & $\begin{array}{c}\text { Equal } \\
\text { variances } \\
\text { not } \\
\text { assumed }\end{array}$ & & & 1.911 & 259.885 & 0.057 & 0.205 & .107 & $-.006-$ & .416 \\
\hline \multirow{2}{*}{$\begin{array}{l}\text { Challenges } \\
\text { for } \\
\text { e- } \\
\text { recruitments } \\
\text { adoption }\end{array}$} & $\begin{array}{c}\text { Equal } \\
\text { variances } \\
\text { assumed } \\
\end{array}$ & 28.771 & .000 & $1.329-$ & 269 & $\underline{0.185}$ & $0.157-$ & .118 & $-.390-$ & .076 \\
\hline & $\begin{array}{c}\text { Equal } \\
\text { variances } \\
\text { not } \\
\text { assumed }\end{array}$ & & & $1.318-$ & 223.135 & 0.189 & $0.157-$ & .119 & $-.392-$ & .078 \\
\hline
\end{tabular}

\section{Discussions and conclusion:}

Companies are trying all the time to find conventional ways to recruit more people and they have discovered that web-based hiring is more efficient than the traditional ways (Aspridis et al, 2013, p.29). Organizations use the technology of e-recruitment because of numerous reasons including attracting candidates, informing benefits about the organization and assessing applicants' knowledge, skills, abilities and other requirements such as personalities (Mat Zin et al, 2016). Effective recruitment policies and practices make a significant contribution to an organization's 
success. It is not simply about placing suitable candidates into jobs it is also about building and developing a flexible and adept workforce to suit the organization's changing and demanding needs. This study was designed to give an overall assessment of effectiveness of using electronic recruitment and selection process in both Travel Agents and Hotels in Egypt.

The results indicated that using e-recruitment in travel agents and hotels was more effective than traditional methods in hiring. The findings showed that there was a statistically significance correlation between all dimensions of e-recruitment process in travel agents and hotels. Moreover there was a significant difference between travel agencies and hotels and this difference was in favor of travel agencies in the dimensions of methods of recruitment and benefits of e-recruitment. On the other hand there is no significant difference between travel agents and hotels in the dimensions of disadvantage of e-recruitment process for hotels.

Although hotels and travel agencies reported that they are depending on similar e-recruiting methods and have similar benefits, the T-test results showed that there is a significant statistical difference between their views on the efficiency of those methods as per their scope of work and operational activities. This referred difference was in favor of travel agencies. Furthermore, the erecruitment's success factors and the disadvantages of e-recruitment adoption were reported in effect equal point of views by travel agencies and hotels. This finding indicated that firstly travel agents have fewer staff than hotels, is easier and faster. Secondly we find that hotels rely mainly on recruitment on personal interviews to select competent staff. On the other hand, because of the lack of policies for e-recruitment in hotels, we find that its defects are more in hotels than travel agents.

The findings showed that there was a statistically significant weak to strong positive relationship between each pair of the study dimensions of e-recruitment process. The high relationships (Strong relationship) were between the dimensions of "benefits of e-recruitment and "success factors of e-recruitment", then between the dimensions of "methods of recruitment" and "success factors of e-recruitment", and between "methods of recruitment" and "benefits of e-recruitment. These findings revealed that the study's variables are precisely related and affect each other positively to the extent that helps in the evaluation of respondents' opinions towards the study dimensions.

The most methods of recruitment being used by both travel agents and hotels in Egypt were social media sites followed by company websites, professional websites and commercial jobs boards. This was agreed with the results of the studies conducted by Kroeze, (2015) and Melanthious et al (2015). The most benefits of e-recruitment for both travel agents and hotels were saving recruitment cost; e-recruitment available 24 hours/7 days; Recruiters can easily access both national and international applicants; and more opportunities for smaller companies. These finding were compatible with the results of the studies of Galanaki (2002), Ramaabaanu and Saranya (2014), Pin et al. 2001, Bartram (2000), Zusman and Landis (2002), McDougall (2001), CIPD (2005) and Mohamed et al (2002).

The most disadvantages of e-recruitment for both travel agents and hotels were the difficulty assurance of source of data and documents and the large number of forms and CVs of applicants. This was compatible with the results of the studies conducted by Ramaabaanu and Saranya 
(2014), Feldman and Klaas (2002) and Pin et al. (2001). The most successful evaluating factors of e-recruitment process in travel agents were increased the performance of required tasks, then interesting of personal standards and qualifications and increased number of responses for every job openings. Otherwise, the most successful factors of e-recruitment process in hotels were the increased percentage of new employee retention within a given timed followed by increased number of submitted applications/ CVs and increased new employee satisfaction rate.

Hence, this study presents many recommendations for hotels and travel agents for an effective erecruitment process. These recommendations can be presented as follow:

- Developing policies and procedures that will promote e-recruitment in the company because of its contribution to reduce the cost of e-recruitment in the company.

- Using variety of more methods of e-recruitment to attract new employee.

- Developing special software that will facilitate the search for the most efficient candidates who submitted their applications through the company's website.

- The need to increase the level of efficiency of e-recruitment through the training of individuals specialized in e-recruitment and through continuous encouragement by senior management to use applications that increase the efficiency of e-recruitment.

- Following the policy of placing the right person in the right place, especially in the circle of e recruitment because it has an effective role in selecting employees.

- Paying attention to personal standards and qualifications of job applicants, which will bring justice to the recruitment process.

\section{References}

Alfus, P. (2000) 'Today's Recruitment Practices Require Traditional and Internet Techniques', Hotel and Motel Management, December

Allen, D., Mahto, R., and Otondo, R. (2007). "Web-based recruitment: Effects of information, organizational brand and attitudes towards a web site on applicant attraction", Journal of Applied Psychology, Vol. 92 No. 6, pp. 16961708 .

Anna B. Holm. (2010). The Effect of E-recruitment On the Recruitment Process: Evidence from Case Studies of Three Danish MNCs, Aarhus University, Denmark.

Aspridis G., Kazantzi V. and Kyriakou D. (2013). Social Networking Websites and Their Effect in Contemporary HumanResource Management - A Research Approach, Mediterranean Journal of Social Sciences Vol. 4, No.1, January 2013

Bartram, D. (2000) 'Internet Recruitment and Selection: Kissing Frogs to Find Princes ,International Journal of Selection and Assessment, Vol 8, No.4, 261-274

Berger, F. and Ghei,A. (1995), "Employment Tests: A Facet of Hospitality Hiring”, Cornell Hotel and Restaurant Administration Quaterly, Vol.36, No.6, pp28-35.

Bozorgi, M. M. (2007). Measuring Service Quality in the Airline Using SERVQUAL Model, Master`s Thesis, Lulea University of Technology, Sweden.

Borck, J.R., 2000. Recruiting Systems Control Resume Chaos. InfoWorld, Vol. 22, No.30, pp. 47-48.

Cappelli, P. (2001) .Making the Most of On-Line Recruiting. Harvard Business Review, vol. 3, No. 79 , pp. $139-146$ 
CIPD (2005) 'Online Recruitment', [online] (cited 7 December 2005) Available from http://www.cipd.co.uk/subjects/recruitmen/onlnrcruit/onlrec.htm?IsSrchRes=1

Cullen, B., 2001. E-Recruiting is Driving HR Systems Integration. Strategic Finance, Vol. 83, No.1, pp. 23-26.

Feldman, D.C. and Klaas, B.S. (2002) 'Internet Job Hunting: A Field Study of Applicant Experiences with On-Line Recruiting', Human Resource Management, Vol. 41, No.2, pp.175-192.

Galanaki, E. (2002), “The Decision to Recruit Online: A Descriptive Study”, Career Development International, Vol.7, No.4, 243-251.

Gamage, A. S. (2014). Recruitment and selection practices in manufacturing SMEs in Japan: Ananalysis of the link with business performance. Ruhuna Journal of Management and Finance, Vol.1, No.1, pp. 37-52.

Ghazzawi, K, and Accoumeh, A. (2014).Critical Success Factors of the E-Recruitment System, Journal of Human Resources Management and Labor Studies, Vol. 2, No. 2, pp. 159-170

Gopalia, A. (2012).Effectiveness of Online Recruitment and Selection Process :A Case of Tesco, Oxford Brookes University

Haley, J. (2000) 'Corporate Recruiting Strategies: More than Ad Placement' [online] (cited 26 January 2000) Available from http://www.halcyon.com/donace/CRM.HTM

Hart, C., Doherty, N and Ellis-Chadwick, F. (2000). Retailer adoption of the Internet Implications for retail marketing. European Journal of Marketing, Vol.34, No.8, pp. 954-974.

Huda, K., Haque, A, and Khan, R. (2014). Effective Recruitment Challenges Faced by the Hospitality Industry in Bangladesh: A Study on Selected Star Rated Residential Hotels, Economia. Seria Management Vol. 17, Iss. 2.

Kaur, P., 2015. E-recruitment: A Conceptual Study. International Journal of Applied Research 2015; 1(8): 78-82

Kerrin M. (2005), “E-Based Recruitment: New Challenges in the Application of Selection and Assessment”, Paper presented at the Division of Occupational PsychologyConference, Warwickshire, UK.

Kroeze, R. (2015).Recruitment via Social Media Sites: A critical Review and Research Agenda, 5th IBA Bachelor Thesis Conference, November 5th, 2015, University of Twente, The Faculty of Behavioural, Enschede, The Netherlands.

Kumar, S., (2003), "Managing Human Capital Supply Chain In The Internet Era”Industrial Management and Data Systems, Vol.103, No. 4, pp. 227-237.

Kumudha. A, and SaranyaPriyadarshini.C (2014).A Conceptual Study on an approach to E-Recruitment and its technological Challenges. International Journal of Application or Innovation in Engineering \& Management (IJAIEM), Vol. 3, Iss. 11, Nov. 2014

Ladkin, A. and Buhalis, D. (2016). Online and Social Media Recruitment: Hospitality Employer and Prospective Employee Considerations, International journal of contemporary hospitality management, Vol. 28.2016, 2, pp. 327345

Lawrence, S. (1999) 'Employment Sites', Iconocast, 10 June, cited in Bartram, D. (2000) 'Internet Recruitment and Selection: Kissing Frogs to Find Princes', International Journal of Selection and Assessment, Vol. 8, No.4, pp.261274.

Mat Zin. S; Nik Jaafar. N; Che Mat. R; Alias. W; Munirah, H; and Ashari. H. (2016). E-Recruitment Technology: The Effective Source of Recruitment, Journal of Applied Environmental and Biological Sciences, 6(1S), pp.84-89.

McDougall, B. (2002) 'Cyber-Recruitment: The Rise of the E-Labour Market and Its Implications for the Federal Public Service', [online] (cited 25 May 2006) Available from http://www.rma-agrh.gc.ca/research/labour-market/erecruitment_e.pdf 
Melanthiou , Y., Pavlou, F, and Constantinou, E. (2015). The Use of Social Network Sites as an E-Recruitment Tool, Journal of Transnational Management, Vol. 20, Issue 1.

Mohamed, A., Orife, J., and Wibowo, K. (2002) 'The Legality of Key Word Search as a Personnel Selection Tool', Employee Relations, Vol 24, No.5, pp.516-522.

Nadda,V; and Rafiq Z; and Tyagi.(2017). Effectiveness and Challenges of Recruitment process outsourcing (RPO) in the Indian Hotel Sector, Munich Personal RePEc Archive (MPRA), No. 77164.

NAS Insights, (2006). "Interent Recruitment Report".

Pin, R.J., Laorden, M. and Sáenz-Diez, I. (2001) 'Internet Recruiting Power: Opportunities and Effectiveness', IESE Research Papers D/439, [online] (cited 25 May 2006) Available from http://www.iese.edu/research/pdfs/DI-0439E.pdf

Piturro, M. (2000) ‘The Power of E-Cruiting', Management Review, Vol 89, No.1, pp. 33-37.

Robson, C. (2002) Real World Research: A Resource for Social Scientists and Practitioner - Researcher. Oxford. Blackwell Publishing.

Saini, P. and Chauhan, S. (2016). E- Recruitment - Easy and Effective Recruitment: A Conceptual Study. International Journal of Core Engineering \& Management (IJCEM), Vol.2, Iss.11, February 2016

Sameen, S, and Cornelius, S. (2013). Social Networking Sites and Hiring: How Social Media Profiles Influence Hiring Decisions, Journal of Business Studies Quarterly 2013, Vol. 7, No. 1

Shahila. D and Vijayalakshmi. R. (2013). E- Recruitment Challenges, International Journal of Social Science \& Interdisciplinary Research, Vol. 2 (5), May (2013)

Sharma,V. (2011). Impact of E-Recruitment on Human Resource Supply chain Management: an empirical investigation of service industry in Indian context, doctor of Philosophy in management, Jaypee Institute of Information Technology, Noida, INDIA.

Singh, L. and Narang, L. 2008. Behavioral Revelation Concerning E-Recruitments. The IUP Journal of Organizational Behaviour, Vol.7, No.4, pp.45-53.

The Public Appointments Service (2006). E-Recruitment Practices andtrends in Ireland, the Public Appointments Service Research Advisory Panel

Zawawi, E. and Kamaruzzaman, S. (2009). Personnel characteristics of maintenance practice: A case of high rise buildings in Malaysia. Journal of Sustainability Development, Vol. 2, No.1, pp.111 - 116.

Zusman, R. and Landis, R. (2002) 'Applicant Preferences for Web-Based versus Traditional Job Postings', Computers in Human Behavior, Vol.18, No.3, pp.285-296. 